\title{
The importance of mother tongue maintenance in international schools
}

\author{
Olja Milošević1 \\ International School of Belgrade, Belgrade, Serbia
}

\begin{abstract}
The increasing mobility of people implies an increasing number of students who start mastering two or more languages. A number of educational institutions provide schooling for different populations of migrant children. International schools are one type of these providers. In order to assist students coming from various language backgrounds, international schools that provide for migrant students have one language of instruction that is, in most cases, different from the language of the host country and from the mother tongues of many students in the school. In that environment, students begin to acquire a second language as soon as they enter an international school, and sadly, their mother tongue development tends to be neglected. Students who follow an international curriculum learn at least two languages, but the lack of sufficient knowledge of their mother tongue impacts their development of literacy and their academic achievement in general. This paper consists of two parts. The first part gives the theoretical implications for the importance of mother tongue maintenance. The second part presents findings from a small-scale study conducted in one international school where the language of instruction is English. The study was carried out with students who acquire two or more languages simultaneously. It deals with the language development of several students in that school and their perspectives on the importance of the mother tongue and the role of English in their education. The findings indicate that students whose mother tongue is maintained seem to have better success in school.
\end{abstract}

Keywords: mother tongue maintenance, English as an Additional Language, international education.

\section{Introduction}

International schools provide education for a very specific group of migrant students. When parents leave their home country to pursue careers, their children accompany them and then find themselves in a situation where they have to learn the language (usually English) of a new community as fast as possible to be integrated in the school community and to be able to function in everyday situations. As Halliday pointed out, students „learn language, they learn through language, and they learn about language" (Halliday, 1988: 36). They acquire very quickly the conversational English that enables them to talk

1 omilosevic@isb.rs 
about everyday topics. However, significantly more time is necessary to reach the level of academic language of their classmates. Acquiring sophisticated language is increasingly difficult for students who are in secondary school. English for them becomes a necessity since it is the language of instruction and they need to master it in order to be educated. It is not surprising that in such a situation students are mainly focused on acquiring the language of instruction.

While they attempt to become proficient in English, the mother tongue development of many students becomes neglected. This is unfortunate because for students who are not native English speakers, it is equally important to master the new language of instruction as it is to maintain their mother tongue. Only if they continue to have opportunities to develop their first language skills in secondary school will they become fully bilingual. That is the reason why governing bodies in many schools undertake measures to promote maintaining the mother tongue.

\section{Theoretical Implications}

In many cases in international education, the language that students learn and that helps them develop cognitively is not their mother tongue. Their education is in their second or third language. Acquiring and becoming proficient in another language is a complex and difficult process that takes many years. Hadaway and Mundy affirm that acquiring a second language is demanding, but also emphasizes that it is not the only task since second-language learners "must also master content concepts and gain the awareness of the skills and strategies needed to become independent learners" (Hadaway \& Mundy, 1999: 473). Cummins has a similar view stating that "the newcomer English language learners in secondary schools are faced with formidable challenges in gaining access to the curriculum and catching up academically" (Cummins, 2007: 2). Secondlanguage students acquire the language in order to be educated, and to do so they need to master not only the new language but also the skills needed for academic success.

The majority of second-language learners experience similar problems during language acquisition (Aukerman, 2007). Students who start their international education early in their lives have time to develop their language skills in the language of instruction. After several years of being in international education, they have a wide age-appropriate vocabulary range, they use idiomatic expressions, and gain a near-native accent. Upon entering secondary school, they often appear to their teachers to speak English as fluently as their peers for whom English is the first language. However, not all of them seem to be able to follow the academic content of the core courses and struggle with academic English. Although many second-language learners seem able to cope with English at school, they may have academic or literacy-related difficulties in class and will still need constant support to acquire sufficient proficiency to be successful in core subjects. Although these students may have learned everyday language and may seem linguistically prepared, they may not have been sufficiently prepared for academic success in their secondary schooling. 
There is a strong correlation between mother tongue development and secondlanguage acquisition. Faulstich Orellana and García Source affirm that „bilinguals draw on their full linguistic toolkits in order to process information, make meaning, and convey it to others" (Orellana \& García, 2014: 386). Goldenberg maintains that „skills such as phonological awareness, decoding, and knowledge of letters and sounds can probably be transferred and that they can help students acquire English" (Goldenberg, 2008). That means that secondlanguage acquisition could be hindered by a lack of development of the mother tongue. Cummins formulated an 'interdependence hypothesis' proposing that second-language competence depends on the level of the mother tongue (Cummins, 1984). An assumption underlying this idea is that the maintenance of the mother tongue can enhance the second language. Cummins argues that oral language development is related across languages and that linguistic and conceptual growth in both first and second languages are caused by the same developmental process. He concludes that "conceptual maturity... is strongly linked to literacy-related and conversational growth in both languages" (Cummins, 1991: 95). This is in accordance with the 'threshold level hypothesis' (Skutnabb-Kangas \& Toukomaa, 1976). This hypothesis proposes that only when children have reached a threshold of competence in their first language can they successfully learn a second language without losing competence in both languages. Students whose mother tongue is not developed will most likely lack competence in the second language.

In situations where students come from a language background that is different from the language of instruction, they will need help to reach proficiency in their mother tongue as well as in English. Barrow and Markman-Pithers point out that "early achievement gaps between English learners and their native English-speaking peers can still translate into lower education achievement" (Barrow \& Markman-Pithers, 2016: 165) adding that "they must continue to develop a strong foundation in their native language while trying to learn English" (Barrow \& Markman-Pithers, 2016: 168). Conger expresses his concern that students who learn English as their second language and who were „immersed in an all-English classroom were not learning English quickly, falling behind in knowledge of subject matter, and losing proficiency in their native languages" (Conger, 2010: 1106). Tran explores the process of language assimilation among the second generation Spanish-speaking population in the United States and points out that "use of English at home and in school has no effect on English acquisition, but significantly promotes Spanish retention" (Tran, 2010: 275). Therefore, promoting the mother tongue should become a priority in international schools.

\section{The Small-Scale Study}

\section{Educational context and participants}

This small-scale study was conducted in a PreK-12 college preparatory international school in Serbia where English is the language of instruction. The school enrolls both Serbian children and non-Serbian children whose parents currently work in the country. Since all teaching is carried out in English (with the exception of foreign language 
courses), students need to have sufficient fluency in written and spoken English. Although there are a number of native English speakers, the majority of students learn English as a second language, and attend additional English classes at some point in their schooling. The school implements International Baccalaureate programs (Resnik, 2012) and in accordance with the programs, the school recognizes the importance of mother tongue maintenance and encourages parents to enroll students in mother tongue courses.

During the last two years of their secondary schooling, the majority of students enroll in the demanding International Baccalaureate Diploma Programme, and students need to have developed very sophisticated language skills to pass exams successfully. When selecting their language courses, all students have to take English. They could take either the English language and literature course, or the English language acquisition course. The former is considered to be for students who have a near-native proficiency in English, and the latter is for students who still need to develop their language skills. Students who do not have the necessary language skills to attend the language and literature course in English are advised to sign up for the English language acquisition course. In this course, English is taught as a foreign language. At the end of the course, students need to demonstrate proficiency in English but not at mother tongue level. It is to be expected that this course would be for students who enter the program at the end of their secondary education.

The participants in this small-scale study were grade 11 students enrolled in the English language acquisition class as part of their Diploma Programme course selection. In this two-year English language acquisition course, there were two distinct groups of students whose mother tongue was not English. Their language proficiency varied but, at the beginning of the course, both groups struggled with academic reading and writing.

The first group consisted of students who had spent a large part of their lives in international education (Students 1, 2, 3 and 4). In some cases, their whole education had been in English in this or some other international school. Their everyday English was outstanding; they used idiomatic expressions, the right registers, and easily became engaged in many aspects of school life. However, their academic language lagged behind the language of their peers and could not fulfill all the requirements of some courses they attended. They struggled with academic language and that was the main reason they were not considered to be English language and literature candidates.

The second group consisted of students who had joined the program for the last two years of their secondary education (Students 5, 6, 7 and 8). Many host country parents recognize the benefits that such a program would bring to their children and they enroll them in the International Baccalaureate Diploma Programme, hoping that the diploma will enable their children to pursue the education they want. Those students were mainly host country citizens. They started learning English very early and had learned English as a foreign language for more than ten years before they entered this school. At the beginning of the course in grade 11, they struggled with academic English. After initially struggling, they made rapid progress. They still had to work on their English, but they had no problem with content in other subjects. They could explain complicated concepts and ideas in their mother tongue, and by the time they were in their second semester, they could express 
understandings in their second language. Over time, they were able to follow other subjects in English, write required text types, deliver oral presentations, and over the twoyear period at this school they established themselves as strong students. They earned good grades not only in English language acquisition, but in other subjects, and passed their exams with distinction. Many of them graduated with honors or high honors.

On the other hand, students who had spent their schooling in an international setting had problems not only with academic English. They struggled with understanding complex ideas in both their mother tongue and in English. It seemed that the lack of mother tongue maintenance impacted their academic success.

\section{Research questions}

Considering the issues raised in the institution and by teacher observations, this qualitative small-scale study was carried out in order to understand why a relatively large number of students who had spent their entire education in one language medium had problems in their secondary education. The research attempted to answer the following research questions:

- How do students perceive the role of the mother tongue in their second language acquisition?

- What academic and social/emotional aspects are affected by the lack of mother tongue maintenance?

\section{Data collection}

The data was gathered from several sources: observations, informal conversations with teachers, and semi-structured in-depth interviews with students over the period of approximately one school year.

Throughout the course, the teacher kept a journal and recorded observations, students' comments, reactions to the tasks, and the feedback they received after they submitted the assignments for marking. The teacher recorded situations that she considered interesting and provided descriptions of several classes during which students raised some questions relevant for the research.

Three core subject teachers were interviewed individually (language and literature teacher, history teacher, and science teacher). One teacher was interviewed twice because some additional explanations were required. The teachers were asked to comment on the language proficiency of the students involved in the study. The interviews allowed teachers to reflect on the students' engagement in their classes, and to articulate their beliefs about the reasons for students' success or lack of it, in their classes. The interviews with the teachers helped to establish what problems those students faced when receiving instruction and mastering the content in a language that is not their mother tongue.

Grade 11 English acquisition students were asked to participate in this research and eight of them accepted the invitation. Five of them were boys and three girls. Two in-depth interviews were conducted with those eight students. Students were interviewed in two groups. The first group consisted of four students who had been in international education 
for a long period of time, and the second group consisted of four students who had joined the school later on. Each interview lasted from 30 to 35 minutes. The interviews generated more information about the students' perspectives on their English language development and the importance of their mother tongue. The open ended-discussion provided an opportunity to probe more deeply and explore students' opinions and concerns.

Each interview was audio-recorded. The responses to the questions were transcribed and then analyzed to seek patterns. Teachers' and students' comments are given verbatim.

\section{Findings and discussion}

\section{Perceptions of students' second-language development}

A student's attitude towards English language development is influenced by his views of himself as an English user. Both groups of students were asked the same question:„How good do you think your English is since you have been placed in the English acquisition class?"The answers from both groups showed that they did not have a realistic picture of their language proficiency. The students who had been in the international school for a long time were overconfident about their English proficiency.

Student $1:$,I am in this class because I do not like reading and I do not like to be in the English literature class."

Student 3: „My English is good, but I just don't like to write.”

This is contrary to the views that their teachers had. Teachers complained that those students did not produce quality work and that they struggled with academic reading and writing. Teachers also pointed out that students from the first group lacked study skills and were usually classified as lazy. Teacher 1 commented that students from the first group often struggled with register and tended to use colloquial language when they needed to use sophisticated historical terminology.

Another teacher showed her surprise at the lack of confidence:

„But it is interesting because I sensed a lack of confidence in their English where I would not have expected it. I wouldn't have thought that because they are confident about everything... I see their reluctance to write something down because they do not know the English word. I wouldn't have thought they would care so much because they act as though they do not care. It is interesting that they feel that lack of confidence even though their English is good."

Another student from this group shared strategies she used to impress teachers.

Student 2: II realize that my English, especially when it comes to reading and writing, is not perfect, but I guess, it was easy for me to fool teachers. I speak English with no accent, I use „big" words, and teachers just assumed I was lazy when my writing wasn't good. As a matter of fact, I'm not sure I can write well at all."

Indeed, it requires more than language skills to use language for academic purposes, and unfortunately, those skills had not been developed in any language. The students from this group struggled with other subjects, could not fulfill all requirements for other courses, and were always treated as students who need constant language support. Although those students had great career aspirations, they failed to meet expectations. 
Students from the second group, those who enrolled later in these institutions, pointed out how much they struggled in school because of a lack of English. They lacked confidence and they did not perceive their English as good, but they did not believe that success was beyond their control.

Student 6: „My English is getting better. I am still looking for basic words.”

Another student was very much aware of his lack of academic skills but showed determination to master them:

Student 7: „My English is still not good, but it is getting better. It is hard to write essays, and I have to learn how to do so."

The perception that students have of their language proficiency influences teachers when forming judgments about the students' progress. Conversations with teachers revealed that teachers do not judge the language proficiency of their students accurately. The reason for this initial error in judgment is due to the fact that students from both groups developed different strategies to deal with problems they had. Students who had joined an international school later in their life struggled to find the right word, and had difficulty with pronunciation and correct grammar usage. This lack of language fluency worked to their advantage. They were easy to identify and teachers normally provided plenty of support during and after class. On the other hand, students who had been educated in English for a long time developed strategies to hide their lack of understanding. Their good command of spoken English put them in a position where they were easily overlooked by the school support system.

At the beginning of the course, students from the second group were described as not mastering the content. When discussing the language problems that students face, one teacher pointed out that she was concerned about one student because of his relatively low level of English. The teacher admitted that she was surprised to discover that the student took part in a number of national math competitions. It is often the case that something that students do well goes unrecognized by teachers, possibly because teachers perceive the students' abilities as limited and then they organize instruction to fit that perception.

\section{The importance of the mother tongue}

Both groups of students were asked to consider the importance of their mother tongue. Responses received from the students who had spent their entire education in an international setting indicate that those students were aware that their command of their mother tongue was not at the level of their peers in schools that followed their national curriculum. At home, their parents did not provide enough support, they did not spend time with peers who would speak to them in Serbian, and the only Serbian language practice they had was during their classes at school. Those students did not necessarily communicate with their parents in their mother tongue. Some of their parents considered their mother tongue as inferior, tried to avoid using it, and insisted on speaking less than good English to their children themselves. This attitude can be seen in the following comment:

Student 2: "My father always insisted on talking to me in English, but his English was not really good. But he was always at work, and we did not talk a lot."

Student 4: „I speak English and German at home. My dad speaks English. The last language I learnt was Serbian. My Serbian is not good, it is OK." 
Students from this group did not think highly of their mother tongue. For them, it is a language they speak with their parents and with some friends. This can be identified in the following comment:

Student 4: „I will not need Serbian in future."

The perception of inferiority of their mother tongue led to a long-term devaluation of their cultural identity and language outside of school.

On the other hand, students from the second group had developed their mother tongue. They used it to communicate outside of school. They talked to their parents and friends in their mother tongue. Their parents had not been educated in English, but they were able to assist their children with subject content in their common language.

Those students did not necessarily consider that their mother tongue was important, but their thought patterns were developed in Serbian. Two students from the group of students who joined the school later commented on their language progress:

Student 5: "My entire education was in Serbian, I think in Serbian... biology ... I know it all in Serbian, but I have to learn the things I know in English."

Student 7: "Speaking Serbian gives me a feeling of being at home. I express feelings and opinions better in Serbian than in another language. I can always say things better in Serbian. My Serbian is better than my English."

Students from the two groups use their mother tongue for different purposes. That was acknowledged both by teachers and by students.

The students from the first group would use Serbian mainly to exclude other students or teachers who do not speak Serbian. The comment from Teacher 2 shows her frustration when describing the students' behavior:

Teacher 2: „When they are yelling across the room, they could be saying anything about me in front of me. They could be talking about things that are inappropriate for school, and I stand like an idiot without any idea."

On the other hand, the same teacher commended the way that students from the second group used their mother tongue.

Teacher 2: „I feel people speak in Serbian when it is a conversation between two people, or when they do not understand something and want to check with someone else who speaks the same language."

Students from the second group who had come to the school recently would use Serbian to help each other understand the content. They did not use Serbian to exclude others, but as a tool to clarify meaning and to process information.

\section{Mother tongue and integration}

Both groups of students struggled with integration. One student from the second group shared his frustration in this way,

Student 5 : „In the first year it was very hard because I could not make many friends at that time and I did not understand anything that was taught. The biggest problem for me was that I could not communicate with people. If we had to do group work, it was very hard and I would be always left out."

It is understandable that those students stayed in contact with their friends. Those contacts helped them with social life, but also to develop their mother tongue. 
Although they have their mother tongue developed, students noticed that the two languages impacted each other.

Student 7: „It is interesting that I am now looking for some words in Serbian. Sometimes, I say something in Serbian and the way I say it comes from English. It is funny that I have problems with English when I am in school, and outside of school I speak silly Serbian."

This comment shows that students were using their metacognitive skills and reflected on language learning.

The students from the first group did not have problems integrating with peers at school, but they did not have many friends outside of school. Their life developed around school and they hardly mixed with their peers from the national system. They are painfully aware that students who are not host country citizens move frequently and that their friendships are often short-lived.

When asked if they have friends who are not from school, many of the students show a lack of willingness to develop relationships.

Student $1:$,It is sad that I have lost so many friends. I develop friendships and then my friends move."

Student 2: „No, I only know the children of my parents' friends"

Student 3: „What would I talk with them about? We are two different worlds."

Since they had not been educated in their mother tongue, they lacked the vocabulary to talk to their peers about complex topics. That may be the reason they avoided the company of their peers who do not speak English well. Those students also experience emotional separation not only from their peers but also from their relatives if their mother tongue is not maintained.

\section{Conclusions, limitations of research, and implications for future research}

This small study has its limitations. The collected data represent the personal opinions of eight students among more than hundreds of students who learn English as an additional language in one institution among several similar institutions in Serbia. In addition, the researcher was also the teacher of those students. The teacher as a researcher attempted to better understand her students and by doing so to improve practice. As such, the data cannot be generalized. However, the students' perspectives on teaching and learning as given in the institution are of particular importance for policy makers in international education and for parents whose children are educated in a language different than their own. The next step would be to conduct a longitudinal study that would track students over several years. Such a study would provide data that would inform both school governing bodies and parents about the importance of maintaining mother tongue.

Since proficiency in the first language is a positive advantage in learning a second language, students whose mother tongue is maintained seem to have better success in school. Students who follow an international curriculum learn at least two languages, but an insufficient command of their mother tongue puts them at a disadvantage when mastering age-appropriate concepts. Mastering concepts seems to depend a lot on 
mother tongue development. On the other hand, students who learn English as a foreign language but who have developed their mother tongue do not experience problems mastering complex, but age appropriate concepts.

In order to be successful in their studies, students need to be proficient in academic language. For students who are enrolled in international education at a very early age, maintaining their mother tongue is the key for developing a second language. These two languages are interdependent. Students use a second language to continue the conceptual development that they started in their mother tongue. It is no surprise that children who have a solid foundation in their mother tongue develop stronger literacy skills in their second language. This becomes especially important during secondary school, when many second-language learners are not able to catch up with native speakers in academic language because they have not developed complex concepts in any language.

The mother tongue can only be maintained if there is enough support from the family. In cases when there is no adequate mother tongue support, parents perceive the mother tongue as an obstacle to their children's second-language development. If that is the case, then the quality of interaction between parents and children will be different and unlikely to promote deeper cognitive and academic skills. Parents transfer those beliefs to their children and by doing so they place value neither on their culture nor language.

Schools are also responsible for promoting mother tongue development. Mastering a language does not only mean being able to speak the language fluently in everyday situations and being able to use advanced vocabulary. Being proficient in a language means being able to speak, read, and write on a variety of academic topics. Therefore, schools need to provide programs that not only support basic competency in the mother tongue, but instruction that is age-appropriate and at the level carried out for native speakers in their national educational system. Developing a mother tongue program would require employing different mother tongue teachers and establishing practices that would allow sufficient time for students to achieve age-appropriate competence in their mother tongue.

\section{References}

Aukerman, M. (2007). A Culpable CALP: Rethinking the Conversational / Academic Language Proficiency Distinction in Early Literacy Instruction. The Reading Teacher, 60(7), 626-635.

Barrow, L., \& Markman-Pithers, L. (2016). Supporting Young English Learners in the United States. The Future of Children, 26(2), 159-183.

Conger, D. (2010). Does Bilingual Education Interfere with English Language Acquisition? Social Science Quarterly, 91(4) 1102-1122.

Cummins, J. (2007). Promoting Literacy in Multilingual Contexts. Retrieved from http://www.edu.gov.on.ca/eng/literacynumeracy/inspire/research/Cummins.pdf

Cummins, J. (1984). Bilingualism and special education: Issues in assessment and pedagogy. Clevedon: Multilingual Matters.

Cummins, J. (1991). The Development of Bilingual Proficiency from Home to School: A Longitudinal Study of Portuguese-Speaking Children. The Journal of Education, 173(2), 85-98. 
Goldenberg, C. (2008). Teaching English Language Learners: What the Research Does and Does Not Say. American Educator, 32(2), 8-24. Retreived from https://www.aft.org/sites/default/files/periodicals/goldenberg.pdf

Halliday, M. A. K. (1988).,"There is Still a Long Way to Go..."An interview with emeritus professor Michael Halliday. Journal of the Australian Advisory Council on Languages and Multicultural Education, 1, 35-39.

Hadaway, N. L., \& Mundy, J. (1999). Children's Informational Picture Books Visit a Secondary ESL Classroom. Journal of Adolescent \& Adult Literacy, 42(6), 464-475.

Orellana, M., \& García, O. (2014). Conversation Currents: Language Brokering and Translanguaging in School. Language Arts, 91(5), 386-392.

Resnik, J. (2012). The Denationalization of Education and the Expansion of the International Baccalaureate. Comparative Education Review, 56(2), 248-269.

Skutnabb-Kangas, T., \& Toukomaa, P. (1976). Teaching migrant children's mother tongue and learning the language of the host country in the context of the socio-cultural situation of the migrant family. Helsinki: Tampere.

Tran, V. C. (2010). English Gain vs Spanish Loss? Language Assimilation among Second - Generation Latinos in Young Adulthood. Social Focus, 89(1), 275-284.

\section{Appendix 1}

Guidelines for in-depth interviews with students

1. How good do you think your English is since you have been placed in the English Acquisition class?

2. How good do you think your mother tongue is?

3. How important is it for you to speak your mother tongue well?

4. Do you read for pleasure in your mother tongue?

5. When you are angry or when you want to express other emotions, what language comes to you naturally?

6. Do you use your mother tongue to talk to your peers during the school day? Do you use it with all students who speak the same language as you do?

7. Do you have friends outside of school?

8. What language do you generally use to talk to your parents?

9. What language do you generally use to talk to your friends outside of school?

\section{Appendix 2}

Guidelines for in-depth interviews with teachers

1. How does MT impact second language acquisition?

2. How is the academic achievement of your students affected by insufficient command of your mother tongue?

3. How is your students' social life affected by the insufficient command of your mother tongue? 
4. How are your students affected emotionally by the insufficient command of your mother tongue?

5. Do you see students using coping strategies in your class?

6. How do ELL (English language learners) cope with academic content in your class?

7. How do ELL (English language learners) interact with other students in your class?

8. What are their main difficulties?

9. How much does language proficiency impact grades?

\title{
Важност очувања матерњег језика у интернационалним школама
}

\author{
Оља Милошевић \\ Интернационална школа у Београду, Београд, Србија
}

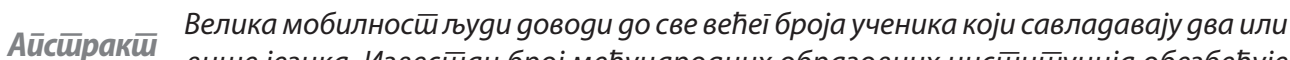

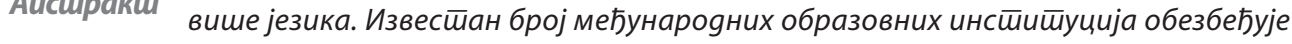

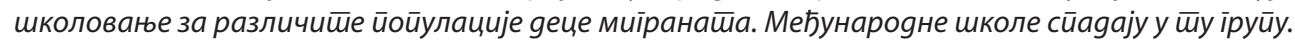
Како би йомоїли gеци која gолазе из различиших језичких среgина, међунароgне школе, које ирружају

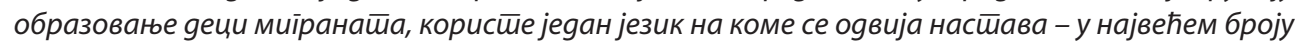
случајева ш̄о је енілески језик - који се разликује оg језика земље у којој се школа налази, као и оg

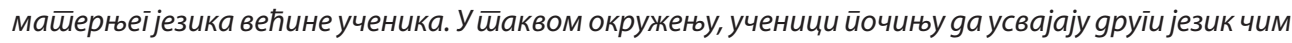

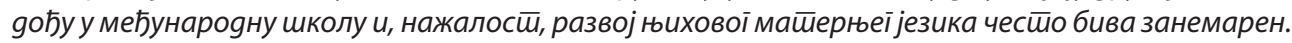

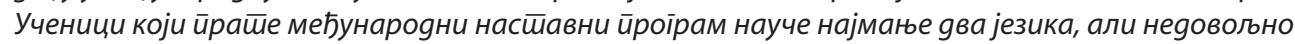

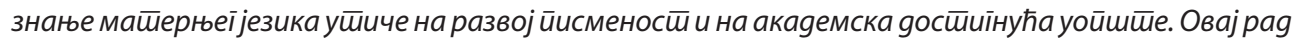
се сасӣоји из gва gела. Први gео навоgи иееоријске имйликачије о важносиии очувања майернеї

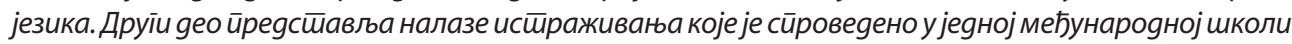
у којој се насйава извоgи на енілеском језику. Исйраживане је сйровеgено међу ученицима који исйовремено усвајају gва или више језика у штој школи. Размаширају се језички развој неколико

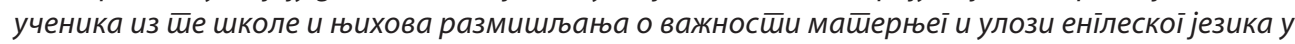

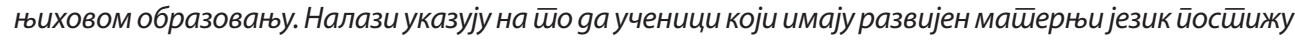
и бољи усиеех у школи.
\end{abstract}

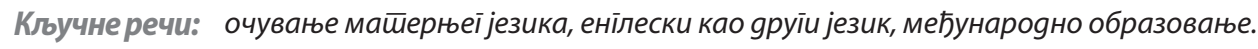




\title{
Важность сохранения родного языка в международных школах
}

\author{
Оля Милошевич \\ Международная школа в Белграде, Белград, Сербия
}

\begin{abstract}
Резюме Высокая мобильность людей приводит к увеличению числа учащихся, владеющих двумя или больше языками. Ряд международных образовательных учреждений предоставляет возможность образования различным группам детей-мигрантов. Международные школы относятся кэтой группе. Чтобы помочь детям из разныхязыковых групп, международные школы, предоставляющие образование детям-мигрантам, используют один язык, на котором осуществляется обучение, - в большинстве случаев это английский, - который отличается от языка страны, в которой расположена школа. и от родного языка большинства учащихся. $B$ такой среде учащиеся начинают изучать второй язык, как только они поступают в международную школу, и, к сожалению, развитием их родного языка часто пренебрегают. Учащиеся, обучающиеся по международной учебной программе, изучают как минимум два языка, но отсутствие знаний родного языка влияет на развитие грамотности и успеваемость в челом. Данная работа состоит из двух частей. В первой части изложены теоретические положения о важности сохранения родного языка. Во второй части представлены результаты исследования, проведенного в международной школе, где обучение ведется на английскиом языке. Исследование проведено среди учащихся, которые одновременно изучали два или больше языков в этой школе. Анализируется языковое развитие нескольких учеников из этой школы и их мнения о важности родного языка и роли английского языка в их образовании. Результаты показывают, что учащиеся с развитым знанием родного языка достигают лучших результатов в школе.
\end{abstract}

Ключевые слова: сохранение родного языка, английский как второй язык, международное образование. 